\title{
Is There a Premium for Elite College Education: Evidence from a Natural Experiment in Japan $\dagger \ddagger$
}

\author{
Taejong Kim* \\ KDI School for Public Policy and Management, Korea
}

May 13, 2004

\begin{abstract}
In a dramatic move to confront the prolonged and often violent student protests on college campuses, the Japanese government ordered that every student repeat the school year at the University of Tokyo in 1969. The move had the inadvertent effect of denying those graduating from high school in that year an opportunity to seek admission to the nation's foremost institution of higher education. This paper uses the highly unusual event as a natural experiment, and examines whether graduates from the elite Tokyo university receive a preferential treatment in hiring and promotion in the high civil service. As a result of the 1969 incident, the entering class in the high civil service four years later in 1973 included a significantly lower proportion of graduates from the University of Tokyo, the traditionally predominant provider of elite bureaucrats, than in usual years. Comparing the career paths of the entering class of 1973 with those of adjacent cohorts, we do find some evidence that where one went to school may matter in the hiring stage, but no significant evidence for a similar favoritism in promotion in later stages.
\end{abstract}

$\dagger J E L$ classification codes: I21, J4, J45.

$\ddagger$ Key words: human capital, college education, elite college, public sector labor market, promotion.

\footnotetext{
*The author feels indebted to Prof. Okita Yoichi and Prof. Kawaguchi Daiji for helpful comments and encouragement. Financial support from the KDI School of Public Policy and Management and the National Graduate Institute for Policy Studies (GRIPS), Japan, is gratefully acknowledged. Yamamoto Fumiko and Jiyoung Lee provided diligent research assistance. Correspondences should be directed to Taejong Kim, KDI School, P.O.Box 184 Cheong-nyang, Seoul 130-650, Korea. The author may also be contacted at tjkim@kdischool.ac.kr via email, or at $+81-(0) 2-3299-1085$ by phone. Preliminary draft.
} 


\section{Introduction}

In a dramatic move to confront the prolonged, and often violent, student protests on college campuses around the country, the Japanese government ordered in January 1969 that every student at the prestigious University of Tokyo repeat the previous academic year, citing the students' failure to meet the minimum class requirement. The move had the inadvertent effect of denying the high school-graduating class of 1969 an opportunity to seek admission to the nation's foremost institution of higher education.

This paper uses this unusual event as a natural experiment to examine whether there is a premium for elite college education for those serving in the government. Four years later, in 1973, the entering class in the high civil service included a significantly lower proportion of graduates from the university. We analyze whether the 1973 cohort experienced discrimination in the hiring and promotion decisions in the government service in comparison to the adjacent cohorts, due to a lower representation of the University of Tokyo graduates in their midst.

The focus on government officials is motivated by two considerations. First, the government sector is well known for the traditionally high concentration of graduates from the Tokyo university, and is arguably most significantly affected by the 1969 admission freeze at the university. Second, if there is favoritism based on where one went to college, it is more likely to show up in the government than in the private sector, the latter being directly exposed to market discipline. The second consideration suggests that whatever impact we may find in the government is likely to provide something akin to an upper bound for similar effects elsewhere in the economy. ${ }^{1}$

Whether there is an extra return to elite college education has been receiving a growing attention. In the U.S., the tuition inflation and the increasing skills premium may help account for the rising interest in the question among both academics and the public at large. In many parts of the developing world, there is a widely shared concern about cronyism, which may be fed partly through formal and informal ties forged among the lucky few

\footnotetext{
${ }^{1}$ In a planned joint work with Abe Naohito, I intend to explore the effects of the University of Tokyo education on boardroom promotions in Japanese corporations, adopting a similar empirical strategy.
} 
during their time together in elite colleges.

Despite several ingenious attempts to be reviewed shortly, answering the question remains a difficult empirical task, essentially because it is difficult to estimate the counterfactual outcome: what would have happened to these bright and ambitious graduates from elite colleges, had they attended a different, lower-ranking, college? The 1969 admission freeze at the University of Tokyo is valuable as a natural experiment, as it provides the missing piece in the puzzle, albeit in the limited institutional context of the government sector in Japan.

We report evidence that the value of the University of Tokyo degree may vary at different stages in the careers of officials. In the hiring stage, government ministries increased both the number of recruits and the proportion of the University of Tokyo graduates among them in the four hiring seasons of 1969, 1970, 1971, and 1972, presumably in anticipation of the coming crunch in 1973, while reducing the number of fresh recruits in 1973 itself. Yet, regression results, using the 1973 entry into the government service as an instrument, suggest that the University of Tokyo degree had little impact on the promotion probabilities in the advanced stages. The evidence is consistent with the view that degrees from elite colleges may serve as a valuable signal in the early stages of labor market experience, when employers have precious little data on job aspirants, while the signal may lose its value in the later stages, once employers have had enough time to observe the true productivity of their workers.

The remainder of the paper proceeds as follows. Section 2 will briefly review the relevant literature. Section 3 introduces the data to be analyzed. Section 4 will present the main results, to be followed by concluding remarks.

\section{Related Literature}

The literature most closely related to the current paper is a small but growing number of papers measuring the impact of college quality on subsequent earnings in the labor market. Behrman, Rosenzweig, and Taubman (1996) and Brewer, Eide, and Ehrenberg (1999) both provide an excellent survey of the literature.

As Ben-Porath (1967) formalized, production of human capital involves three main in- 
puts: (a) human capital endowed to individuals, including inherent ability and family endowments, (b) time spent for investment in human capital, and (c) other purchased inputs. That these three types of inputs are likely to be correlated with each other presents a tough empirical challenge to an investigator trying to estimate a causal impact of any of the factors on subsequent labor market outcomes.

For instance, consistent estimation of returns to schooling requires in principle that the right hand side of the regression equation have all the variables listed above. To circumvent the considerable data requirement, some researchers have relied on twins studies or instrumental variables empirical strategies based on institutional changes in the education system. The returns-to-schooling literature is a fine example whereby complementary empirical strategies have successfully contributed to a deeper understanding of the empirical relationships under investigation, as superbly surveyed by Card (1999).

Estimation of the impact of school (or college) quality on subsequent earnings presents a similar hurdle in data requirement. Earlier empirical studies, while striving to control for observables, usually failed to measure all of the inputs in the human capital production function. For instance, Solmon (1973), Wachtel (1976), and Altonji (1988), among others, used test scores to control for ability along with school quality measures. The test scores, however, may not only measure endowments incompletely and imperfectly, but may also reflect the influence of school inputs in earlier stages, as noted by Behrman, Rosenzweig, and Taubman (1996). It is worth emphasizing that representing school quality by inputs at a given school level is not sufficient. To measure the impact of quality of college one attended, for instance, we should include quality indicators not just for college, but for all school levels to which one has been exposed. To the extent that these (unobserved) variables as well as family endowments are positively correlated with input indicators at the college level, OLS estimates are likely to overstate the true impact of college quality on earnings.

Ono (forthcoming in Industrial Relations) studies the relationship between college quality and earnings in the Japanese labor market. The study controls for individual ability, using the respondent's self-reported grade point average in ninth grade. As pointed out by Behrman, Rosenzweig, and Taubman (1996), however, failure to control for family backgrounds and for input quality at different levels of schooling may still be biasing the OLS 
estimates.

Several recent studies adopted careful and ingenious empirical strategies to adjust for selection on unobserved variables. Brewer, Eide, and Ehrenberg (1999) explicitly model high school students' choice of college type based on individual and family characteristics, and estimate selectivity-corrected outcome equations. Behrman, Rosenzweig, and Taubman (1996) difference out unobserved individual and family characteristics using twins data. Dale and Krueger (2002) compare college quality and earnings among students who were accepted and rejected by a comparable set of colleges, and are comparable in terms of observable variables.

The current paper complements the studies above in three ways. First, to our best knowledge, the paper is the first to take advantage of a natural experiment that allows us to examine what would have happened to those who attended an elite college, had they attended a less selective college. Second, we study the impact of elite college education on hiring and promotion, instead of earnings. In the context of long-term employment practices in Japan, promotion within the organization is closely accompanied by increased earnings. Third, examining the separate impacts of elite college education on hiring at the entry level and on promotion in later stages is likely to yield informative results bearing on the different roles played by elite education as a signal in different stages of one's life cycle.

\section{Data and Institutional Backgrounds}

The data come from two sources: seikan yōran and Hata (2003). seikan yōran is a directory of politicians and high-ranking government officials serving in the Diet, the nation's parliament, and the central government ministries. The biannual publication covers government officials above the rank of assistant section chief, and provides information on the current rank and post, the year of entry into the government service, and basic biographic data such as birthday, birthplace, the name of college one graduated from, and the college major. Hata (2003) lists the names of individuals who entered the government service after passing the highly competitive Civil Service Exam, Class I, by ministry and entry year as well as the name of college they attended before joining the ministry. 
We use the data from Hata (2003) for two purposes. First, we trace the changes in the number of fresh recruits and the proportion of graduates from the University of Tokyo, Faculty of Law (UTL, hereafter), around 1973. This allows us to examine whether and how the ministries adjusted their hiring policy, anticipating the consequences of the 1969 admission freeze at the University of Tokyo. We also use the information to identify those who entered the civil service through the Civil Service Exam, Class I, among those listed in various issues of seikan yōran.

The civil service in Japan recruits new entrants through a system of examinations that are stratified both hierarchically and functionally. Hierarchically, there are two classes of exams, Class I and Class II. Class I is the more selective entrance gate for elite bureaucrats. The system promotes Class II entrants at a slower pace, and places a promotion ceiling for them at the middle management level. Functional division in the exams breaks down into administration, law, economics, psychology, and miscellaneous fields in engineering, agriculture, and forestry. Of them, the first three fields of administration, law, and economics, collectively called hōbunkei, constitute the backbone of the central government's elite bureaucracy. Despite their relatively small number, ${ }^{2}$, hōbunkei officials traditionally dominate in the key posts in the chain of command and the critical posts for external liaison. In the remainder of the paper, we focus on Class I höbunkei officials, and analyze the patterns of hiring and promotion with emphasis on UTL graduates.

\section{Results}

In this section, we present evidence on the effects of UTL degree on hiring and subsequent promotion in the ministries. We will argue based on the evidence that UTL graduates may indeed receive a preferential treatment in the hiring stage, and that this advantage vanishes in later stages for promotion decisions at higher ranks in the ministerial hierarchy. The later dissipation of the preferential effects suggests that the apparent initial premium probably reflects the signaling value of elite degree in the presence of difficulties in prediction of the

\footnotetext{
${ }^{2}$ In 1996, for instance, the government hired 780 fresh recruits in Class I. Of those, administration, law, and economics fields accounted for 33, 157, and 95, respectively, totaling 285 or roughly one third of the total. See Hata (2003), p. 622.
} 
true productivity of a worker, rather than favoritism based on school ties.

\subsection{Effects of UTL on hiring}

Table 1 presents the total number of fresh recruits and UTL graduates by ministry and by year. ${ }^{3}$ Perhaps the most striking feature of the recruiting practices is the high proportion of UTL graduates hired each year. Except for the year 1973, the share of UTL graduates among new hires hovers around or above 50 percent. In the powerful Ministry of Finance, the share is consistently above 50 percent. The pattern is similar in the Ministry of International Trade and Industry. The Ministry of Home Affairs sets the record with rates almost always above 70 percent. $^{4}$

The other remarkable feature in Table 1 is of course the significant drop in both the number of recruits and the proportion of UTL graduates in the year 1973 against the backdrop of higher-than- usual comparable figures for the adjacent cohorts. The Figures 1-3 vividly show the depth of the drop in 1973, for all ministries, Ministry of Finance, and Ministry of Home Affairs, respectively.

Regressions reported in the Appendix quantify the responses of the ministries to the 1969 admission freeze. The outcome variables are the total number of recruits and the proportion of UTL graduates among them, by ministry and year, respectively. In addition to the ministry dummies, ${ }^{5}$ the regression equations include three period dummies for year 1973, the two-year period leading up to the 1973 crunch (1971-2), and lastly the two-year

\footnotetext{
${ }^{3}$ The table exhausts all the ministries headed by a cabinet minister, with the exception of the Ministry of Foreign Affairs. The ministry has its own exam to select professional diplomats. Due to frequent postings overseas, officials in the ministry are hard to trace through issues of seikan yōran. For these reasons, we exclude the ministry from the analysis.

${ }^{4}$ The shares of graduates from the University of Tokyo as a whole are at a slightly higher level. As Johnson (1982) explains, the University of Tokyo has always provided the greatest number of applicants who pass the examinations, because of its original orientation toward education for government service, as well as general excellence. The other important Faculty relatively well represented in the composition of elite bureaucrats is the Faculty of Economics. The remaining portion is accounted for by graduates from Kyoto University, Tōhoku University, Hitotsubashi University, and some others. For reference, during 1977 about 53,000 people took the Class I Civil Service Examination, and only about 1,300 passed, a ratio of 1 passer to 41 applicants. (Johnson (1982))

${ }^{5}$ The omitted category is the ministry of education.
} 
period in the wake of the crunch (1974-5). The coefficient estimates for the period dummies suggest that the ministries responded by increasing both the total number of recruits and the proportion of UTL graduates among them in the periods surrounding the 1973 crunch, so that they could afford to take in a fewer number of recruits and a lower proportion of UTL graduates in 1973 itself.

Interpretation of these results hinges on whether the quality of applicants' pools remained similar in and around 1973. If it did, the results must mean that UTL graduates receive a favorable treatment in the hiring stage, while it is unclear whether it reflects a favoritism based on school ties or difficulties in measurement of the true productivity and the value of UTL degree as a signal of productivity. ${ }^{6}$

\subsection{Effects of UTL on promotion afterward}

Next we turn to the effect of UTL degree on promotion probabilities. We will marshal various kinds of evidence, ranging from Kaplan-Meier survival estimates and statistical tests for equality of survival curves to instrumental variables estimates and duration models, in support of the view that discrimination based on where one went to college does not exist in later stages for promotion. As Chalmers Johnson (1982) explains, promotion is virtually guaranteed for all Class I officials up to the level of section chief. To reach the rank of section chief may take about 18 years in the Ministry of Finance and there are slight variations across ministries. The competition for promotion is made explicit from the rank of section chief. Gates for promotion get more and more narrow, as one advances to higher ranks. ${ }^{7}$

Since the promotion system is characterized by "up or out" competition, as emphasized by Inatsugu (1996), promotion patterns may be conveniently compared through survival

\footnotetext{
${ }^{6}$ It is certainly possible that the quality of the pool in the 1973 recruiting season was lower than in usual years. Young students' preferences may be malleable and easily influenced by the prevailing norms in the college they attend. If the norms in universities other than UT tend to discourage future careers in government, then some of those talented students who might have elected to take the government service exam, had they entered UT in 1969, may have chosen careers in the private sector due to their exposure to non-UT environments.

${ }^{7}$ After section chief, the typical path takes the order of chief of General Affairs Section in an external agency, chief in one of the Secretariat Sections, deputy chief or department head, internal bureau chief, Director-general of an external bureau, and finally (administrative) vice-minister, the top position for career officials.
} 
curves. Figure 4 presents Kaplan-Meier survival estimates for UTL graduates (broken lines) and others (solid lines). The diagram clearly shows that survival rates are always higher for UTL graduates. Indeed, the Peto-Peto test statistic for equality of two survival curves is $\chi^{2}(1)=8.84$, with the p-value of 0.003 . The results may seem to suggest that UTL graduates keep receiving a preferential treatment even in advanced stages of their career. It is not clear, however, whether the results reflect favoritism or superior productivity of UTL graduates.

A different pattern emerges when we compare survival rates of 1973 and the adjacent entry cohorts. Figure 5 presents Kaplan-Meier survival estimates by entry years. 1972 entry cohort is represented by a solid line, 1973 cohort by a broken line, and 1974 cohort by a dotted line. Based on the figure, survival patterns do not show any significant differences between entry cohorts. ${ }^{8}$ Between 1973 entry cohort and the remaining cohorts, the PetoPeto test statistic for equality of two survival curves is $\chi^{2}(1)=0.22$, with the p-value of 0.640: we cannot reject the null hypothesis that two survival curves are indistinguishable.

Tables 2-4 present and compare OLS and IV estimates of the effects of UTL degree on survival probabilities, conditional on survival up to the twentieth year in government service. The outcome variable in Table 2 is a dummy assuming the value of unity if the individual is still in the government in the 22nd year. The outcome variables are similar survival dummies for the 24 th year and for the 26th year, respectively. ${ }^{9}$ In each table, model (1) is a simple regression of the survival dummy on the UTL dummy; models (2) controls for entry year, place of birth, and ministry; model (3) controls additionally for entry age. Age at entry into ministry may serve as a rough proxy for ability: the smarter set may pass the exam while in college and join the ministry upon graduation, while the less smart may take longer to make the cut.

OLS estimates for the UTL coefficient are not terribly large, but they do grow with the time period allowed. For instance, OLS estimates in Table 4 suggest that survival premium

\footnotetext{
${ }^{8}$ We get a similar conclusion when we throw in more cohorts, but we present this figure for better legibility.

${ }^{9}$ It should be noted that the longevity of the 1973 entry cohort is right censored in the 27th year, since our data covers only up to year 2000. After 2000, the administrative reform considerably changed the jurisdictions of ministries and personnel compositions between ministries.
} 
accruing to UTL degree may be in the range of 7 to 9 percent for survival up to 26th year (conditional on survival up to 20th year). However, these estimates are likely to be contaminated due to omitted variables bias, and overstate the true impact if promotion (and thus survival) partly depends on unobserved ability and if unobserved ability is positively correlated with UTL degree.

IV estimates circumvent this problem by using the 1973 entry dummy as an instrument. As first stage regression results demonstrate in Table 6, the 1973 entry dummy is significantly correlated with UTL degree dummy at different time points, even after controlling for a host of covariates. ${ }^{10}$ In addition, we argue that the 1973 entry dummy is not correlated with unobserved ability, if the quality of applicants' pools is comparable in and around $1973 .{ }^{11}$ In contrast to the OLS estimates, IV estimates are either negative or indistinguishable from zero. Provided that our identifying assumption is valid, these results are consistent with the view that UTL graduates do not enjoy a premium for promotion, once they are hired.

To those who find the results surprising, we must point out that our results may reflect the promotion practices in the Japanese government and also the fact that we are examining the UTL effects after twenty years since individuals joined the government service. The Japanese government makes a point of promoting all Class I officials in a parallel manner for roughly 18 years, up to the level of section chief. Officials are allowed to experience various posts in and out of their ministry, and are closely evaluated for their performance. Almost twenty years of data should be sufficient to reveal the true productivity of the individual, and a degree from UTL or elsewhere may be superfluous as a signal for ability.

Finally, Table 7 presents estimation results of duration models. All models are im-

\footnotetext{
${ }^{10}$ That the value of coefficient estimates for the 1973 entry dummy remains stable at about 35 percent, and is close to the initial deficit in the proportion of UTL graduates in the 1973 cohort compared to the other cohorts is interesting. The fact reflects that the proportion of UTL graduates in the 1973 entry cohort virtually stayed the same throughout the years. This suggests that UTL graduates' and the others' survival rates are about the same.

${ }^{11}$ Unfortunately, we do not have a rigorous, and easily available, way to test this key identifying assumption. One possibility might be to examine the fluctuation in the numbers of applicants in and around 1973, and particularly the numbers of applicants from elite universities. Another possibility might be to conduct interviews with those were responsible for ministerial hiring back in 1973.
} 
plemented as proportional hazard models with the Weibull distribution. ${ }^{12}$ The ancillary parameter $p$ is invariably significantly larger than unity regardless of model specification, meaning the baseline hazard increases exponentially over time. The presented numbers for explanatory variables are hazard ratios, or exponentiated coefficients. If the hazard ratio for a variable is greater than one, then an increase in the value of the variable expedites exits (termination of government career in the context of the current paper), or raises the hazard rates. In contrast, a hazard ratio less than 1 means that an increase in the value of the corresponding variable will decrease the hazard rates. ${ }^{13}$ Standard errors are given within the parentheses.

The UTL dummy is shown to clearly decrease the hazard rates in model (1) (without controls for covariates) and model (3) (with covariates). Similar to OLS estimates, however, these estimates may be confounding the true effects of UTL degree with the effects of unobserved individual heterogeneity. Models (2) (without controls) and (4) (with controls) focus on the effects of the 1973 entry dummy instead. The estimated hazard ratios are less than one for the 1973 entry dummy. Recall that 1973 is the cohort with a smaller share of UTL graduates than the others. Therefore the results in (2) and (4) imply that, informally controlling for unobserved ability, UTL degree has the effects of raising the hazard rates, even though the impacts are statistically indistinguishable from one.

\section{Concluding Remarks}

We used in this paper the 1969 admission freeze at the University of Tokyo as a natural experiment to examine the effects of elite college (University of Tokyo, Faculty of Law) education on hiring and promotion probabilities for the Japanese government's elite civil servants. Simply comparing promotion probabilities between UTL graduates and the others, as in OLS and comparable methods, runs the risk of committing an omitted variables bias. In contrast, our approach has the effect of indirectly controlling for unobserved ability or

\footnotetext{
${ }^{12}$ Kiefer (1988) is an elegant introduction to duration models.

${ }^{13}$ Hazard rates are a function of duration $t$ and represent the rate at which spells (government careers) will be completed at duration $t$, given that they last until $t$.
} 
unobserved individual heterogeneity that may be correlated with UTL degree.

The results suggest that while there may or may not be discrimination based on where one went to school in the initial hiring stage, any such effects have vanished as long as promotion decisions are concerned at senior levels. The patterns suggest that if UTL graduates did receive a favorable treatment in the hiring stage, that is probably because of the value of UTL degree as a signal for productivity, not because of favoritism based on school ties. Since cronyism based on school ties is less likely to matter in the private sector exposed to market discipline, our finding augurs well for a similar problem in the private sector.

We note the following limitations in our study.

While there may be little discrimination based on survival, there still may be discrimination in terms of assignment to important and less important posts. We plan to examine this possibility in a further study. There are well known key posts in each individual ministry that any vice-minister hopeful is required to have served in. We should be able to check whether the members of the 1973 entry cohort were shunned in assignment to these coveted posts.

Our interpretation of the results critically hinges on the validity of the key identifying assumption: the quality of applicants' pools was comparable between the 1973 and the other cohorts. We need to explore ways to test this assumption.

\section{References}

Altonji, Joseph G. , "The Effects of High School Curriculum on Education and Labor Market Outcomes.", mimeo, Northwestern University(1988).

Behrman, Jere R., Mark R. Rosenzweig, and Paul Taubman. "College Choice and Wages: Estimate Using Data on Female Twins," Review of Economics and Statistics, Vol. 78, No. 4 (Nov. 1996), pp. 672-685.

Ben-Porath, Yoram , "The Production of Human Capital and the Life Cycle of Earnings," Journal of Political Economy, Vol. 75 (July 1967, Part 1), pp. 352-365.

Betts, Julian R. , "Does School Quality Matter? Evidence from the National Longitudi- 
nal Survey of Youth," this Review, Vol. 77(May 1995), pp. 231-250

Brewer, Dominic J., Eric R. Eide, and Ronald G. Ehrenberg. "Does it Pay to Attend an Elite Private College?: Cross-Cohort Evidence on the Effects of College Type on Earnings," Journal of Human Resources, Vol. 34 (Winter 1999), pp. 104-23.

Card, David. "Causal Effect of Education on Earnings," in Orley C. Ashenfelter and David Card ed. Handbook of Labor Economics Vol. 3A, 1999, pp. 1801-1863.

Card, David, and Alan B. Krueger, "School Quality and Black-White Relative Earnings: A Direct Assessment," Quarterly Journal of Economics, Vol. 107(Feb. 1992a), pp. $151-200$.

Dale, Stacy Berg, and Alan B. Krueger. "Estimating the Payoffs to Attending a More Selective College: An Application of Selection on Observables and Unobservable", Quarterly Journal of Economics, Vol. 117, Issue 4 (November 2002), pp. 1491-1258.

Eide, Eric, Dominic J. Brewer, and Ronald G. Ehrenberg. "Does It Pay to Attend an Elite Private College? Evidence on the Effects of Undergraduate College Qaulity on Graduates School Attendance?", Economics of Education Review, Vol. 17, No. 4.

Inatsugu, Hiroaki. nihon no kanryō jinji sisutemu (Personnel Management Practices in the Japanese Government), 1996, pp. 31-32, Tōyō Keizai Shimpōsha (in Japanese).

Johnson, Chalmers. "Chapter 2 The Economic Bureaucracy" in MITI and the Japanese Miracle: The Growth of Industrial Policy 1925-1975, 1982, Stanford University Press.

Johnson, Chalmers. Chapters 6-7 in Japan, Who Governs?: The Rise of the Developmental State, 1995, Norton.

Kiefer, Nicholas M. "Economic Duration Data and Hazard Functions," Journal of Economic Literature Vol. 26 (June 1988), pp. 646-679.

McPherson, Michael, S., and Morton Owen Schapiro. , Keeping College Affordable, Washington, D. C.: The Brookings Institution. 
Ono, Hiroshi. "College Quality and Earnings in the Japanese Labor Market," Industrial Relations, forthcoming

Solmon, Lewis. "The Definition and Impact of College Quality," Does College Matter: Some Evidence on the Impacts of Higher Education, Lewis Solmon and Paul Taubman. New York: Academic Press.

Solmon, Lewis. "The Definition of College Quality and its Impact on Earnings.", Exploration in Economics Research, Vol. 2, , pp. 537-87.

Solmon, Lewis, and Paul Wachtel "The Effects on Income of Type of College Attended.", Sociology of Education, Vol. 48, pp. 75-90.

Wachtel, Paul. "The Effect on Earnings of School and College Investment Expenditures.", Review of Economics and Statistics, Vol. 58, pp. 326-31.

Wise, David. "Academic Achievement and Job Performance." American Economic Review, Vol.65, pp. 350-66. 
Table 1: The Number of New Recruits and UTL Graduates, by Ministry and Year

\begin{tabular}{|c|c|c|c|c|c|c|c|c|c|c|}
\hline Ministry & & 1967 & 1968 & 1969 & 1970 & 1971 & 1972 & 1973 & 1974 & 1975 \\
\hline \multirow[t]{3}{*}{ Construction } & Total & 13 & 10 & 14 & 14 & 18 & 16 & 14 & 14 & 15 \\
\hline & UTL & 7 & 6 & 7 & 8 & 12 & 11 & 4 & 5 & 8 \\
\hline & $\%$ UTL & 53.8 & 60.0 & 50.0 & 57.1 & 66.7 & 68.8 & 28.6 & 35.7 & 53.3 \\
\hline \multirow[t]{3}{*}{ Health \& Welfare } & Total & 9 & 9 & 11 & 16 & 9 & 11 & 10 & 12 & 17 \\
\hline & UTL & 4 & 9 & 9 & 10 & 8 & 8 & 3 & 5 & 11 \\
\hline & $\%$ UTL & 44.4 & 100.0 & 81.8 & 62.5 & 88.9 & 72.7 & 30.0 & 41.7 & 64.7 \\
\hline \multirow[t]{3}{*}{ Home Affairs } & Total & 14 & 17 & 18 & 16 & 14 & 20 & 8 & 17 & 17 \\
\hline & UTL & 11 & 11 & 13 & 13 & 14 & 18 & 3 & 14 & 13 \\
\hline & \%UTL & 78.6 & 64.7 & 72.2 & 81.3 & 100.0 & 90.0 & 37.5 & 82.4 & 76.5 \\
\hline \multirow[t]{3}{*}{ Labor } & Total & 9 & 13 & 12 & 8 & 11 & 12 & 7 & 8 & 14 \\
\hline & UTL & 2 & 1 & 2 & 2 & 3 & 8 & 2 & 3 & 5 \\
\hline & $\%$ UTL & 22.2 & 7.7 & 16.7 & 25.0 & 27.3 & 66.7 & 28.6 & 37.5 & 35.7 \\
\hline \multirow[t]{3}{*}{ Transportation } & Total & 15 & 12 & 17 & 17 & 16 & 17 & 20 & 17 & 17 \\
\hline & UTL & 10 & 6 & 12 & 10 & 12 & 11 & 2 & 11 & 9 \\
\hline & \%UTL & 66.7 & 50.0 & 70.6 & 58.8 & 75.0 & 64.7 & 10.0 & 64.7 & 52.9 \\
\hline \multirow[t]{3}{*}{ Finance } & Total & 23 & 22 & 21 & 22 & 23 & 24 & 17 & 27 & 27 \\
\hline & UTL & 13 & 11 & 15 & 13 & 12 & 13 & 1 & 15 & 17 \\
\hline & $\%$ UTL & 56.5 & 50.0 & 71.4 & 59.1 & 52.2 & 54.2 & 5.9 & 55.6 & 63.0 \\
\hline \multirow[t]{3}{*}{ EPA } & Total & 7 & 7 & 8 & 8 & 9 & 6 & 6 & 9 & 7 \\
\hline & UTL & 0 & 0 & 0 & 0 & 1 & 0 & 1 & 1 & 0 \\
\hline & \%UTL & 0.0 & 0.0 & 0.0 & 0.0 & 11.1 & 0.0 & 16.7 & 11.1 & 0.0 \\
\hline
\end{tabular}


Table 1: The Number of New Recruits and UTL Graduates, by Ministry and Year (continued)

\begin{tabular}{|c|c|c|c|c|c|c|c|c|c|c|}
\hline \multirow[t]{2}{*}{$\begin{array}{l}\text { Int'I Trade \& } \\
\text { Industryustry }\end{array}$} & Total & 20 & 19 & 20 & 19 & 19 & 19 & 20 & 20 & 25 \\
\hline & $\begin{array}{l}\text { UTL } \\
\text { \%UTL }\end{array}$ & $\begin{array}{c}12 \\
60.0\end{array}$ & $\begin{array}{c}9 \\
47.4\end{array}$ & $\begin{array}{c}11 \\
55.0\end{array}$ & $\begin{array}{c}8 \\
42.1\end{array}$ & $\begin{array}{c}13 \\
68.4\end{array}$ & $\begin{array}{c}10 \\
52.6\end{array}$ & $\begin{array}{c}3 \\
15.0\end{array}$ & $\begin{array}{c}11 \\
55.0\end{array}$ & $\begin{array}{c}13 \\
52.0\end{array}$ \\
\hline \multirow{2}{*}{$\begin{array}{c}\text { Agri. } \\
\text { Forestry \& } \\
\text { Fisheries }\end{array}$} & Total & 10 & 13 & 10 & 16 & 19 & 20 & 14 & 16 & 16 \\
\hline & $\begin{array}{c}\text { UTL } \\
\% U T L\end{array}$ & $\begin{array}{c}4 \\
40.0\end{array}$ & $\begin{array}{c}7 \\
53.8\end{array}$ & $\begin{array}{c}7 \\
70.0\end{array}$ & $\begin{array}{c}6 \\
37.5\end{array}$ & $\begin{array}{c}6 \\
31.6\end{array}$ & $\begin{array}{c}7 \\
35.0\end{array}$ & $\begin{array}{c}5 \\
35.7\end{array}$ & $\begin{array}{c}7 \\
43.8\end{array}$ & $\begin{array}{c}12 \\
75.0\end{array}$ \\
\hline \multirow[t]{5}{*}{ Education } & Total & 11 & 14 & 14 & 10 & 11 & 12 & 10 & 12 & 10 \\
\hline & $\begin{array}{c}\text { UTL } \\
\% U T L\end{array}$ & $\begin{array}{c}1 \\
9.1\end{array}$ & $\begin{array}{c}2 \\
14.3\end{array}$ & $\begin{array}{c}5 \\
35.7\end{array}$ & $\begin{array}{c}1 \\
10.0\end{array}$ & $\begin{array}{c}6 \\
54.5\end{array}$ & $\begin{array}{c}8 \\
66.7\end{array}$ & $\begin{array}{c}4 \\
40.0\end{array}$ & $\begin{array}{c}2 \\
16.7\end{array}$ & $\begin{array}{c}4 \\
40.0\end{array}$ \\
\hline & total & 131 & 136 & 145 & 146 & 149 & 157 & 126 & 152 & 165 \\
\hline & UTL & 64 & 62 & 81 & 71 & 87 & 94 & 28 & 74 & 92 \\
\hline & \%UTL & 49 & 46 & 56 & 49 & 58 & 60 & 22 & 49 & 56 \\
\hline
\end{tabular}


Table 2. Effects of UTL education on survival: $20-22$

\begin{tabular}{|c|c|c|c|c|c|c|}
\hline & \multicolumn{2}{|c|}{ (1) } & \multicolumn{2}{|c|}{ (2) } & \multicolumn{2}{|c|}{ (3) } \\
\hline & OLS & IV & OLS & IV & OLS & IV \\
\hline \multirow[t]{2}{*}{ UTL } & 0.0360 & -0.0313 & 0.0308 & -0.0902 & 0.0252 & -0.0806 \\
\hline & $(0.0171) *$ & $(0.0731)$ & $(0.0177)$ & $(0.0731)$ & $(0.0176)$ & $(0.0719)$ \\
\hline \multirow[t]{2}{*}{ Entry age } & & & & & -0.0098 & -0.0143 \\
\hline & & & & & $(0.0073)$ & $(0.0080)^{+}$ \\
\hline \multirow[t]{2}{*}{ Entry year } & & & -0.0143 & -0.0163 & -0.0129 & -0.0145 \\
\hline & & & $(0.0042) *$ & $(0.0045) * *$ & $(0.0042) *$ & $(0.0044) *$ \\
\hline \multirow[t]{2}{*}{ Tokyo } & & & 0.0187 & 0.0280 & 0.0164 & 0.0238 \\
\hline & & & $(0.0215)$ & (0.0228) & (0.0213) & (0.0223) \\
\hline \multirow[t]{2}{*}{ Kansai } & & & 0.0052 & -0.0082 & 0.0008 & -0.0119 \\
\hline & & & $(0.0263)$ & $(0.0281)$ & $(0.0261)$ & $(0.0279)$ \\
\hline \multirow[t]{2}{*}{ EPA } & & & 0.1094 & 0.0760 & 0.0795 & 0.0485 \\
\hline & & & $(0.0500) *$ & $(0.0550)$ & $(0.0499)$ & $(0.0548)$ \\
\hline Communicati & & & 0.0829 & 0.1129 & 0.0507 & 0.0730 \\
\hline ons & & & $(0.0417) *$ & $(0.0463) *$ & $(0.0421)$ & $(0.0454)$ \\
\hline \multirow[t]{2}{*}{ Agriculture } & & & 0.0025 & 0.0224 & -0.0274 & -0.0128 \\
\hline & & & 0.0411 & $(0.0438)$ & $(0.0413)$ & $(0.0432)$ \\
\hline \multirow[t]{2}{*}{ Home Affairs } & & & 0.0558 & 0.1118 & 0.0226 & 0.0664 \\
\hline & & & $(0.0457)$ & $(0.0572)^{+}$ & $(0.0462)$ & $(0.0553)$ \\
\hline Health & & & -0.0060 & 0.0256 & -0.0366 & -0.0122 \\
\hline Welfare & & & $(0.0433)$ & $(0.0481)$ & $(0.0435)$ & $(0.0472)$ \\
\hline Int'l Trade & & & 0.0126 & 0.0267 & -0.0208 & -0.0127 \\
\hline \multicolumn{2}{|l|}{ and Industry. } & & $(0.0383)$ & $(0.0402)$ & $(0.0389)$ & $(0.0401)$ \\
\hline \multirow[t]{2}{*}{ Finance } & & & 0.0675 & 0.0864 & 0.0320 & 0.0431 \\
\hline & & & $(0.0373)^{+}$ & $(0.0399) *$ & (0.0383) & (0.0398) \\
\hline \multirow[t]{2}{*}{ Construction } & & & -0.0163 & 0.0087 & -0.0488 & -0.0312 \\
\hline & & & $(0.0424)$ & $(0.0460)$ & $(0.0429)$ & $(0.0452)$ \\
\hline \multirow[t]{2}{*}{ Labor } & & & -0.0622 & -0.0702 & -0.0938 & -0.1037 \\
\hline & & & $(0.0491)$ & $(0.0507)$ & $(0.0492)^{+}$ & $(0.0507) *$ \\
\hline \multirow{2}{*}{$\begin{array}{l}\text { Transportati } \\
\text { on }\end{array}$} & & & 0. 0309 & 0.0526 & -0.0025 & 0.0120 \\
\hline & & & $(0.0390)$ & $(0.0420)$ & $(0.0396)$ & $(0.0416)$ \\
\hline \multirow[t]{2}{*}{ constant } & 0.9119 & 0.9471 & 28.9854 & 32.9883 & 26.5292 & 29.8343 \\
\hline & $(0.0124) * *$ & $(0.0392) * *$ & $(8.3250) *$ & $(8.8608) * *$ & $(8.2348) *$ & $(8.6817) *$ \\
\hline
\end{tabular}

Standard errors in parentheses ${ }^{+}$significant at $10 \%,{ }^{*}$ significant at $5 \%,{ }^{* *}$ significant at $1 \%$. The instrument is the dummy for entry in 1973. 
Table 3. Effects of UTL education on survival: 20-24

\begin{tabular}{|c|c|c|c|c|c|c|}
\hline & \multicolumn{2}{|c|}{ (1) } & \multicolumn{2}{|c|}{ (2) } & \multicolumn{2}{|c|}{ (3) } \\
\hline & OLS & IV & OLS & IV & OLS & IV \\
\hline \multirow[t]{2}{*}{ UTL } & 0.0551 & -0.1302 & 0.0432 & -0.2517 & 0.0363 & -0.2451 \\
\hline & $(0.026) *$ & $(0.1120)$ & $(0.0261)^{+}$ & $(0.1120) *$ & $(0.0261)$ & $(0.1109) *$ \\
\hline \multirow[t]{2}{*}{ Entry age } & & & & & -0.0289 & -0.0408 \\
\hline & & & & & $(0.0108) *$ & $(0.0123) *$ \\
\hline \multirow[t]{2}{*}{ Entry year } & & & -0.0312 & -0.0361 & -0.02981 & -0.03471 \\
\hline & & & $(0.0062) * *$ & $(0.0069) * *$ & $(0.0062) * *$ & $(0.0068) * *$ \\
\hline \multirow[t]{2}{*}{ Tokyo } & & & 0.0278 & 0.0503 & 0.0226 & 0.0423 \\
\hline & & & $(0.0316)$ & (0.0349) & $(0.0315)$ & $(0.0344)$ \\
\hline \multirow[t]{2}{*}{ Kansai } & & & 0.0217 & -0.0109 & 0.0130 & -0.0206 \\
\hline & & & $(0.0387)$ & $(0.0431)$ & $(0.0385)$ & $(0.0430)$ \\
\hline \multirow[t]{2}{*}{ EPA } & & & 0.3383 & 0.2567 & 0.2987 & 0.2162 \\
\hline & & & $(0.0734) * *$ & $(0.0841) *$ & $(0.0736) * *$ & $(0.0845) *$ \\
\hline \multirow[t]{2}{*}{ Communications } & & & 0.3060 & 0.3792 & 0.2552 & 0.3144 \\
\hline & & & $(0.0612) * *$ & $(0.0709) * *$ & $(0.0621) * *$ & $(0.0670) * *$ \\
\hline \multirow[t]{2}{*}{ Agriculture } & & & 0.1320 & 0.1803 & 0.0886 & 0.1274 \\
\hline & & & $(0.0604) *$ & $(0.0671) *$ & $(0.0610)$ & $(0.0667)+$ \\
\hline \multirow[t]{2}{*}{ Home Affairs } & & & 0.1620 & 0.2986 & 0.1057 & 0.2224 \\
\hline & & & $(0.0671) *$ & $(0.0877) *$ & $(0.0682)$ & $(0.0852) *$ \\
\hline Health & & & 0.1420 & 0.2189 & 0.0960 & 0.1608 \\
\hline Welfare & & & $(0.0636) *$ & $(0.0737) *$ & $(0.0642)$ & $(0.0727) *$ \\
\hline Int'l Trade and & & & 0.1184 & 0.1530 & 0.0649 & 0.0865 \\
\hline Industry. & & & $(0.0562) *$ & $(0.0616) *$ & $(0.0575)$ & $(0.0618)$ \\
\hline \multirow[t]{2}{*}{ Finance } & & & 0.2369 & 0.2830 & 0.1766 & 0.2062 \\
\hline & & & $(0.0548) * *$ & $(0.0611) * *$ & $(0.0566) *$ & $(0.0614) *$ \\
\hline \multirow[t]{2}{*}{ Construction } & & & 0.1316 & 0.1927 & 0.0794 & 0.1264 \\
\hline & & & $(0.0623) *$ & $(0.0704) *$ & $(0.0633)$ & $(0.0698)+$ \\
\hline \multirow[t]{2}{*}{ Labor } & & & 0.0469 & 0.0274 & 0.0006 & -0.0258 \\
\hline & & & $(0.0722)$ & $(0.0777)$ & $(0.0727)$ & $(0.0781)$ \\
\hline \multirow[t]{2}{*}{ Transportation } & & & 0.2038 & 0.2567 & 0.1497 & 0.1884 \\
\hline & & & $(0.0573) * *$ & $(0.0644) * *$ & $(0.0586) *$ & $(0.0641) *$ \\
\hline \multirow[t]{2}{*}{ constant } & 0.7952 & 0.8922 & 62.1612 & 71.9221 & 60.1688 & 68.9610 \\
\hline & $(0.0186) * *$ & $(0.0600) * *$ & $(12.2213) * *$ & $(13.5776) * *$ & $(12.1631) * *$ & $(13.3865) * *$ \\
\hline
\end{tabular}

Standard errors in parentheses ${ }^{+}$significant at $10 \%,{ }^{*}$ significant at $5 \%,{ }^{* *}$ significant at $1 \%$

The instrument is the dummy for entry in 1973. 
Table 4. Effects of UTL education on survival: 20-26

\begin{tabular}{|c|c|c|c|c|c|c|}
\hline & \multicolumn{2}{|c|}{ (1) } & \multicolumn{2}{|c|}{ (2) } & \multicolumn{2}{|c|}{ (3) } \\
\hline & OLS & IV & OLS & IV & OLS & IV \\
\hline \multirow[t]{2}{*}{ UTL } & 0.0895 & 0.0968 & 0.0793 & -0.0489 & 0.0693 & -0.0490 \\
\hline & $(0.0344) *$ & $(0.1360)$ & $(0.0346) *$ & $(0.1449)$ & $(0.0347) *$ & $(0.1452)$ \\
\hline \multirow[t]{2}{*}{ Entry age } & & & & & -0.0422 & -0.0475 \\
\hline & & & & & $(0.0142) *$ & $(0.0157) *$ \\
\hline \multirow[t]{2}{*}{ Entry year } & & & -0.0284 & -0.0333 & -0.0274 & -0.0319 \\
\hline & & & $(0.0097) *$ & $(0.0112) *$ & $(0.0097) *$ & $(0.0111) *$ \\
\hline \multirow[t]{2}{*}{ Tokyo } & & & -0.0374 & -0.0264 & -0.0424 & -0.0329 \\
\hline & & & $(0.0414)$ & $(0.0435)$ & $(0.0412)$ & $(0.0431)$ \\
\hline \multirow[t]{2}{*}{ Kansai } & & & 0.0223 & 0.0119 & 0.0098 & -0.0011 \\
\hline & & & $(0.0511)$ & $(0.0528)$ & $(0.0510)$ & $(0.0530)$ \\
\hline \multirow[t]{2}{*}{ EPA } & & & 0.3391 & 0.3036 & 0.2933 & 0.2577 \\
\hline & & & $(0.0969) * *$ & $(0.1053) *$ & $(0.0977) *$ & $(0.1072) *$ \\
\hline Communicatio & & & 0.4493 & 0.4801 & 0.3916 & 0.4149 \\
\hline ns & & & $(0.0811) * *$ & $(0.0886) * *$ & $(0.0828) * *$ & $(0.0879) * *$ \\
\hline \multirow[t]{2}{*}{ Agriculture } & & & 0.1156 & 0.1298 & 0.0737 & 0.0840 \\
\hline & & & $(0.0797)$ & (0.0819) & $(0.0806)$ & $(0.0821)$ \\
\hline \multirow[t]{2}{*}{ Home Affairs } & & & 0.0282 & 0.0864 & -0.0280 & 0.0206 \\
\hline & & & (0.0868) & $(0.1085)$ & $(0.0883)$ & $(0.1061)$ \\
\hline Health & & & 0.16044 & 0.1962 & 0.1201 & 0.1502 \\
\hline Welfare & & & $(0.0851)+$ & $(0.0944) *$ & $(0.0858)$ & $(0.0936)$ \\
\hline Int'l Trade & & & 0.1209 & 0.1373 & 0.0672 & 0.0779 \\
\hline and Industry. & & & (0.0736) & $(0.0764)+$ & $(0.0752)$ & $(0.0769)$ \\
\hline \multirow[t]{2}{*}{ Finance } & & & 0.3207 & 0.3391 & 0.2581 & 0.2695 \\
\hline & & & $(0.0718) * *$ & $(0.0752) * *$ & $(0.0741) *$ & $(0.0759) * *$ \\
\hline \multirow[t]{2}{*}{ Construction } & & & 0.3139 & 0.3424 & 0.2612 & 0.2831 \\
\hline & & & $(0.0808) * *$ & $(0.0873) * *$ & $(0.0821) *$ & $(0.0868) *$ \\
\hline \multirow[t]{2}{*}{ Labor } & & & 0.2289 & 0.2222 & 0.1831 & 0.1738 \\
\hline & & & $(0.0963) *$ & $(0.0975) *$ & $(0.0970)+$ & $(0.0984)+$ \\
\hline \multirow{2}{*}{$\begin{array}{l}\text { Transportatio } \\
\mathrm{n}\end{array}$} & & & 0.4273 & 0.4527 & 0.3688 & 0.3871 \\
\hline & & & $(0.0748) * *$ & $(0.0805) * *$ & $(0.0767) * *$ & $(0.0804) * *$ \\
\hline \multirow[t]{2}{*}{ constant } & 0.6233 & 0.6195 & 56.3018 & 66.1183 & 55.5216 & 64.4736 \\
\hline & $(0.0247) * *$ & $(0.0721) * *$ & $(19.122) *$ & $(22.1037) *$ & $(19.0519) *$ & $(21.9626) *$ \\
\hline
\end{tabular}

Standard errors in parentheses ${ }^{+}$significant at $10 \%,{ }^{*}$ significant at $5 \%,{ }^{* *}$ significant at $1 \%$

The instrument is the dummy for entry in 1973. 
Table 5. Impacts of UTL education on survival: a sequential look

\begin{tabular}{|c|c|c|c|}
\hline & $20-22$ & $22-24$ & $24-26$ \\
\hline \multirow[t]{2}{*}{ UTL } & -0.0806 & -0.1934 & 0.1001 \\
\hline & $(0.0719)$ & $(0.0970) *$ & (0.1379) \\
\hline \multirow[t]{2}{*}{ Entry age } & -0.0143 & -0.0302 & -0.0212 \\
\hline & $(0.0080)+$ & $(0.0108) *$ & (0.0155) \\
\hline \multirow[t]{2}{*}{ Entry year } & -0.0145 & -0.0229 & -0.0130 \\
\hline & $(0.0044) *$ & $(0.0060) * *$ & (0.0104) \\
\hline \multirow[t]{2}{*}{ Tokyo } & 0.0238 & 0.0264 & -0.0453 \\
\hline & (0.0223) & (0.0299) & (0.0419) \\
\hline \multirow[t]{2}{*}{ Kansai } & -0.0118 & -0.0104 & 0.0320 \\
\hline & $(0.0279)$ & $(0.0376)$ & $(0.0490)$ \\
\hline \multirow[t]{2}{*}{$\mathrm{EPA}$} & 0.0485 & 0.1701 & 0.1424 \\
\hline & $(0.0549)$ & $(0.0731) *$ & $(0.1071)$ \\
\hline \multirow[t]{2}{*}{ Communications } & 0.0729 & 0.2581 & 0.2304 \\
\hline & $(0.0454)$ & $(0.0601) * *$ & $(0.0828) *$ \\
\hline \multirow[t]{2}{*}{ Agriculture } & -0.0128 & 0.1359 & -0.0084 \\
\hline & $(0.0432)$ & $(0.0579) *$ & $(0.0822)$ \\
\hline \multirow[t]{2}{*}{ Home Affairs } & 0.0664 & 0.1730 & -0.1220 \\
\hline & $(0.0553)$ & $(0.0736) *$ & (0.1002) \\
\hline \multirow[t]{2}{*}{ Health \& Welfare } & -.01223 & 0.1738 & 0.0928 \\
\hline & $(0.0472)$ & $(0.0631) *$ & $(0.0900)$ \\
\hline \multirow[t]{2}{*}{ Int'l Trade and Industry. } & -0.0127 & -0.1001 & 0.0102 \\
\hline & $(0.0401)$ & $(0.0544)+$ & $(0.0777)$ \\
\hline \multirow[t]{2}{*}{ Finance } & 0.0431 & 0.1723 & 0.1550 \\
\hline & (0.0398) & $(0.0530) *$ & $(0.0756) *$ \\
\hline \multirow[t]{2}{*}{ Construction } & -0.0312 & 0.1597 & 0.2325 \\
\hline & $(0.0453)$ & $(0.0616) *$ & $(0.0848) *$ \\
\hline \multirow[t]{2}{*}{ Labor } & -0.1037 & 0.0616 & 0.2426 \\
\hline & $(0.0507)$ & (0.0704) & $(0.1021) *$ \\
\hline \multirow[t]{2}{*}{ Transportation } & 0.0120 & 0.1807 & 0.2930 \\
\hline & $(0.0416)$ & $(0.0555) *$ & $(0.0785) * *$ \\
\hline \multirow[t]{2}{*}{ Constant } & 29.8343 & 46.7466 & 26.6737 \\
\hline & $(8.6817) *$ & $(11.8274) * *$ & $(20.5998)$ \\
\hline
\end{tabular}

Standard errors in parentheses ${ }^{+}$significant at $10 \%,{ }^{*}$ significant at $5 \%,{ }^{* *}$ significant at $1 \%$. The models are all estimated by 2SLS with the 1973 entry dummy as an instrument. 
Table 6. First Stage Regressions

\begin{tabular}{|c|c|c|c|}
\hline & \multicolumn{3}{|c|}{ Dependent variable: UTL } \\
\hline & Up 20 years & Up 22 years & Up 24 years \\
\hline \multirow[t]{2}{*}{ entry73 } & -0.3564 & -0.3547 & -0.3563 \\
\hline & $(0.0469) * *$ & $(0.0486) * *$ & $(0.0515) * *$ \\
\hline \multirow[t]{2}{*}{ entryage } & -0.0414 & -0.0404 & -0.0374 \\
\hline & $(0.0135) *$ & $(0.0142) *$ & $(0.0160) *$ \\
\hline \multirow[t]{2}{*}{ Entry year } & -0.0043 & -0.0039 & -0.0015 \\
\hline & $(0.0079)$ & $(0.0083)$ & $(0.0090)$ \\
\hline \multirow[t]{2}{*}{ Tokyo } & 0.0537 & 0.0599 & 0.0790 \\
\hline & $(0.0398)$ & $(0.0409)$ & $(0.0434)+$ \\
\hline \multirow[t]{2}{*}{ Kansai } & -0.1504 & -0.1454 & -0.1200 \\
\hline & $(0.0487) *$ & $(0.0503) *$ & $(0.0533) *$ \\
\hline \multirow[t]{2}{*}{$\mathrm{EPA}$} & -0.3047 & -0.3243 & -0.4268 \\
\hline & $(0.0927) *$ & $(0.0940) *$ & $(0.1015) * *$ \\
\hline \multirow[t]{2}{*}{ Communications } & 0.2060 & 0.1962 & 0.0950 \\
\hline & $(0.0783) *$ & $(0.0803) *$ & $(0.0885)$ \\
\hline \multirow[t]{2}{*}{ Agriculture } & 0.1402 & 0.1144 & 0.0158 \\
\hline & $(0.0771)+$ & $(0.0805)$ & $(0.0909)$ \\
\hline \multirow[t]{2}{*}{ Home Affairs } & 0.4184 & 0.4114 & 0.3297 \\
\hline & $(0.0852) * *$ & $(0.0877) * *$ & $(0.0980) *$ \\
\hline \multirow[t]{2}{*}{ Health \& Welfare } & 0.2210 & $(0.0848) *$ & 0.0803 \\
\hline & $(0.0809) *$ & & $(0.0947) *$ \\
\hline \multirow[t]{2}{*}{ Int'l Trade and Industry. } & 0.0743 & 0.0881 & -0.0258 \\
\hline & $(0.0727)$ & $(0.0758)$ & $(0.0861)$ \\
\hline \multirow[t]{2}{*}{ Finance } & 0.0978 & 0.0797 & 0.0133 \\
\hline & $(0.0715)$ & $(0.0739)$ & $(0.0832)$ \\
\hline \multirow[t]{2}{*}{ Construction } & 0.1758 & 0.1820 & 0.0786 \\
\hline & $(0.0799) *$ & $(0.0839) *$ & $(0.0935)$ \\
\hline \multirow[t]{2}{*}{ Labor } & -0.0926 & -0.1109 & -0.1864 \\
\hline & $(0.0919)$ & $(0.0985)$ & $(0.1110)+$ \\
\hline \multirow[t]{2}{*}{ Transportation } & 0.1530 & 0.1314 & 0.0473 \\
\hline & $(0.0740) *$ & $(0.0769)+$ & $(0.0861)$ \\
\hline \multirow[t]{2}{*}{ constant } & 9.9967 & 9.197114 & 4.3218 \\
\hline & (15.6064) & (16.4183) & (17.6061) \\
\hline
\end{tabular}

Standard errors in parentheses. ${ }^{+}$significant at $10 \%,{ }^{*}$ significant at $5 \%,{ }^{* *}$ significant at $1 \%$. 
Table 7. Impact on Hazard rates (proportional hazard, Weibull distribution)

\begin{tabular}{|c|c|c|c|c|}
\hline & (1) & (2) & (3) & (4) \\
\hline \multirow[t]{2}{*}{ UTL } & 0.7920 & & 0.7847 & \\
\hline & $(0.0631) *$ & & $(0.0671) *$ & \\
\hline \multirow[t]{2}{*}{ entry73 } & & 0.9470 & & 0.8323 \\
\hline & & $(0.1195)$ & & $(0.1105)$ \\
\hline \multirow[t]{2}{*}{ Entryage } & & & 1.1319 & 1.1380 \\
\hline & & & $(0.0376) * *$ & $(0.0372) * *$ \\
\hline \multirow[t]{2}{*}{ Entry year } & & & 1.0556 & 1.0692 \\
\hline & & & $(0.0234) *$ & $(0.0241) *$ \\
\hline \multirow[t]{2}{*}{ Tokyo } & & & 0.9543 & 0.9197 \\
\hline & & & $(0.1012)$ & $(0.0975)$ \\
\hline \multirow[t]{2}{*}{ Kansai } & & & 0.8131 & 0.8131 \\
\hline & & & $(0.1068)$ & $(0.1071)$ \\
\hline \multirow[t]{2}{*}{ EPA } & & & 0.8169 & 0.8892 \\
\hline & & & $(0.1978)$ & $(0.2138)$ \\
\hline \multirow[t]{2}{*}{ Communications } & & & 0.6808 & 0.6574 \\
\hline & & & $(0.1510)+$ & $0.1457+$ \\
\hline \multirow[t]{2}{*}{ Agriculture } & & & 1.2907 & 1.2819 \\
\hline & & & $(0.2572)$ & $(0.2560)$ \\
\hline \multirow[t]{2}{*}{ Home Affairs } & & & 1.6216 & 1.4760 \\
\hline & & & $(0.3471) *$ & $(0.3124)+$ \\
\hline \multirow[t]{2}{*}{ Health \& Welfare } & & & 0.9616 & 0.9284 \\
\hline & & & $(0.2080)$ & $(0.2009)$ \\
\hline Int'l Trade and & & & 1.3912 & 1.3966 \\
\hline Industry. & & & $(0.2596)+$ & $(0.2620)+$ \\
\hline \multirow[t]{2}{*}{ Finance } & & & 0.8607 & 0.8549 \\
\hline & & & $(0.1648)$ & $(0.1644)$ \\
\hline \multirow[t]{2}{*}{ Construction } & & & 1.3348 & 1.3069 \\
\hline & & & $(0.2671)$ & $(0.2620)$ \\
\hline \multirow[t]{2}{*}{ Labor } & & & 1.0171 & 1.0507 \\
\hline & & & $(0.2376)$ & $(0.2453)$ \\
\hline \multirow[t]{2}{*}{ Transportation } & & & 0.7149 & 0.7140 \\
\hline & & & $(0.1458)$ & $(0.1459)+$ \\
\hline \multirow[t]{2}{*}{$/ \ln \_\mathrm{p}$} & 1.8919 & 1.8856 & 1.9863 & 1.98293 \\
\hline & $(0.0345) * *$ & $(0.0346) * *$ & $(0.0358) * *$ & $(0.0358) * *$ \\
\hline \multirow[t]{2}{*}{$\mathrm{P}$} & 6.6320 & 6.5905 & 7.2888 & 7.2640 \\
\hline & $(0.2287)$ & $(0.2277)$ & $(0.2607)$ & $(0.2598)$ \\
\hline \multirow[t]{2}{*}{$1 / p$} & 0.1508 & 0.1517 & 0.1372 & 0.1377 \\
\hline & $(0.0052)$ & $(0.0052)$ & $(0.0050)$ & $(0.0050)$ \\
\hline
\end{tabular}


Figure 1. Total number of recruits and UTL graduates: 1967-1975

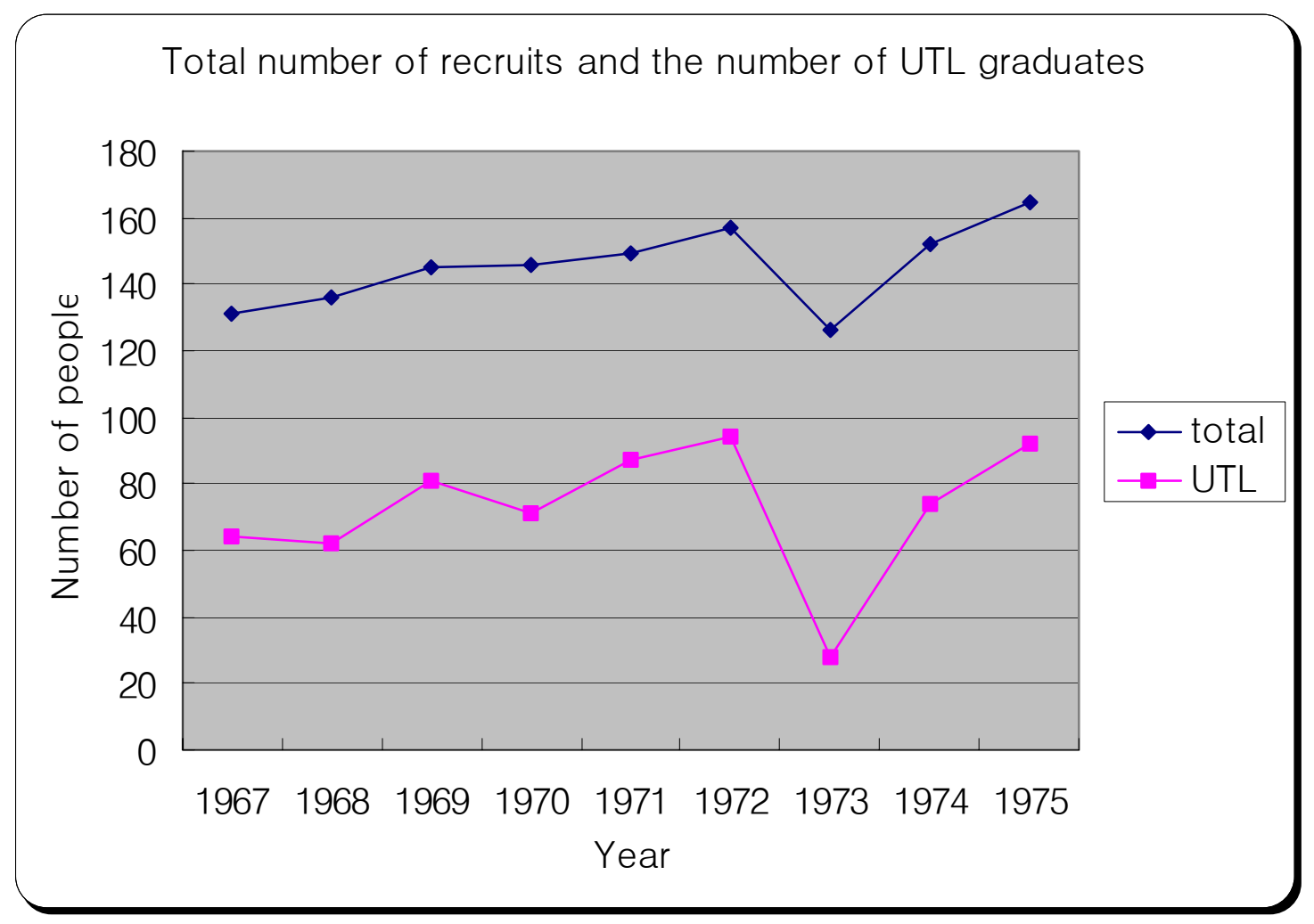


Figure 3. Total number of recruits and UTL graduates: Ministry of Home Affairs

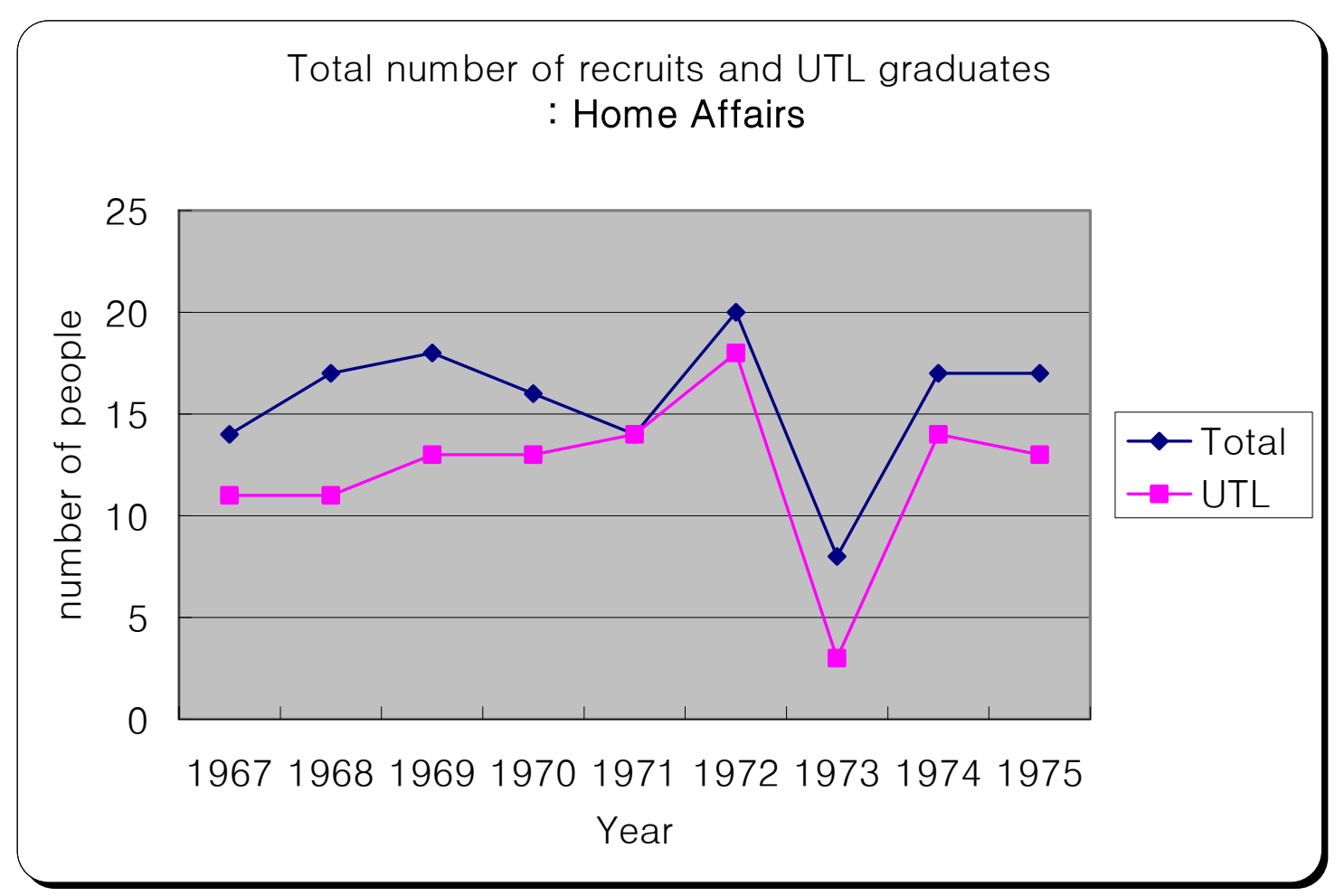


Figure 4. Kaplan-Meier survival estimates by UTL

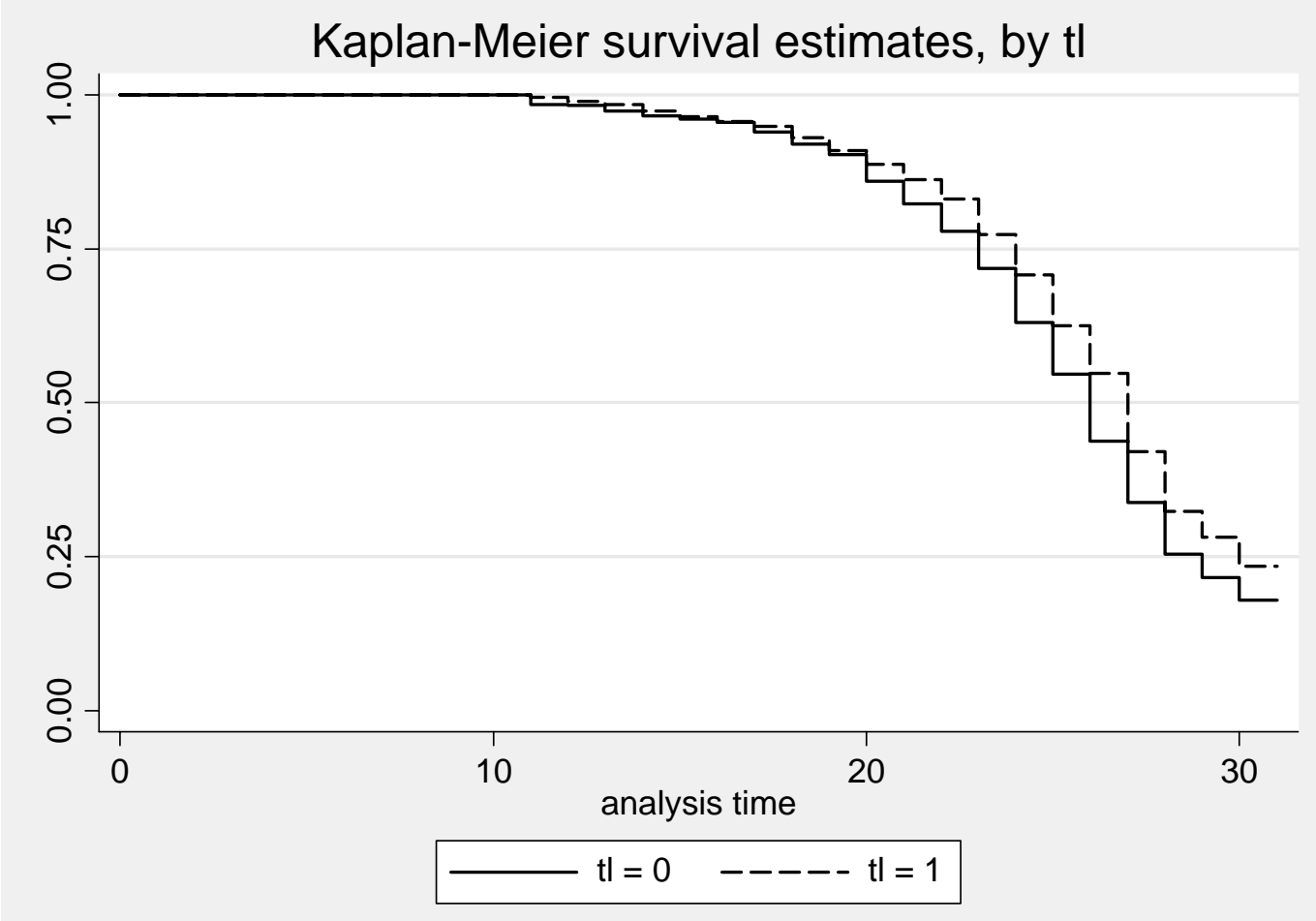


Figure 5. Kaplan-Meier survival estimates, by entry year

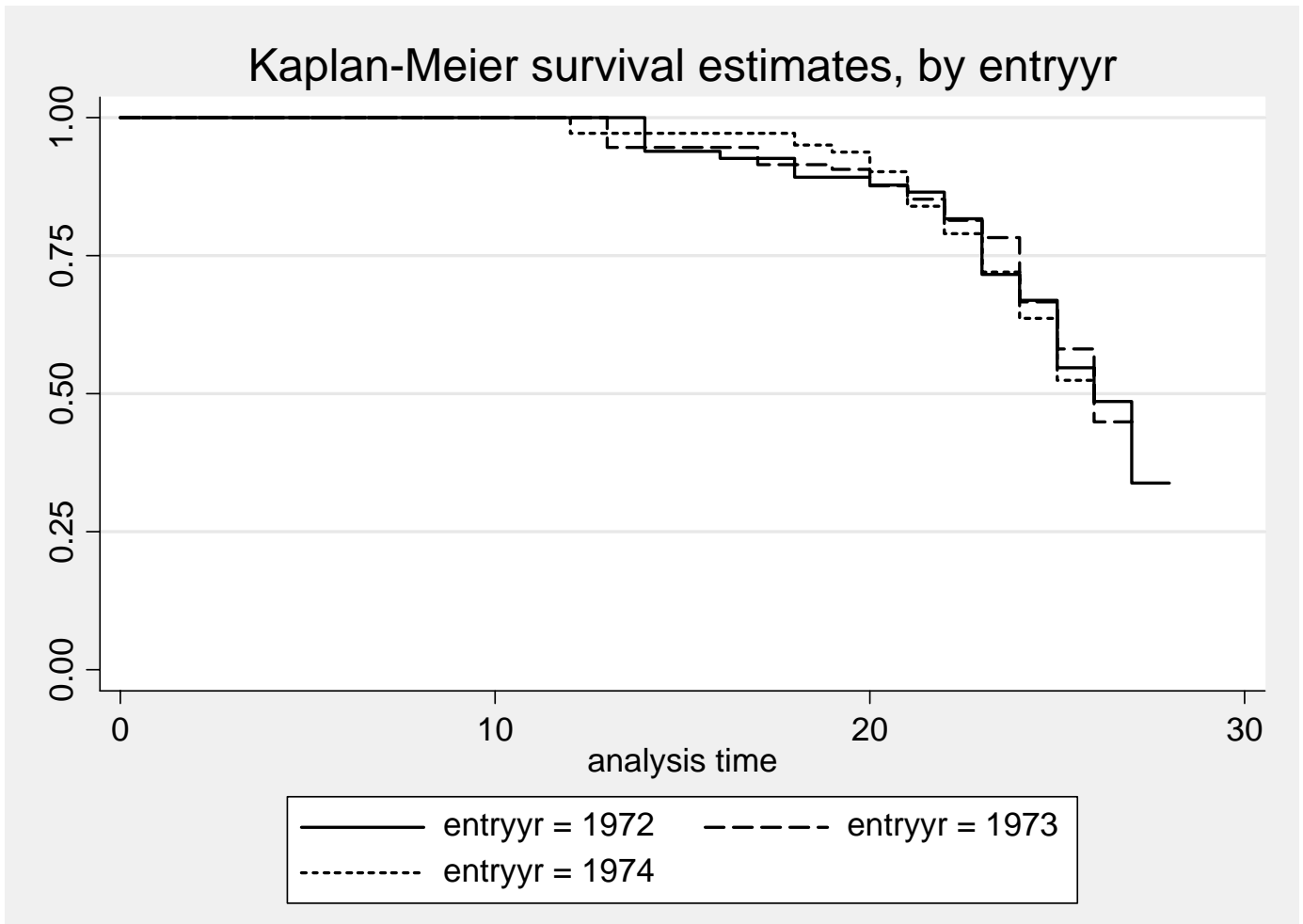




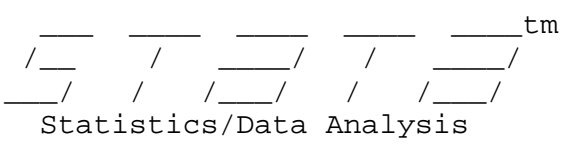

log: e: \data\ut\do\utl.smcl

log type: smcl

opened on: 12 May 2004, 16:34:04

1 . infile str20 ministry entryyr total utl using e:\data\ut \datafiles \utl

'entryyr' cannot be read as a number for entryyr [1]

'Total' cannot be read as a number for total[1]

'utl' cannot be read as a number for utl[1]

(91 observations read)

2 .

3 . gen utlp=utl/total

( 1 missing value generated)

4 . label variable utlp "proportion of utl grads"

5 . label variable utl "num of utl grads"

6 . label variable total "num of new recruits by min by $y$ " $^{\prime}$

7 .

8 . gen maff=ministry=="maff"

9 . gen moe=minist $\mathrm{r}==="$ moe"

10 . gen mof=ministry=="mof"

11 . gen mot=ministry=="mot"

12 . gen moc=minist $\mathrm{y}==" \mathrm{moc} "$

13 . gen epa=ministry=="epa"

14 . gen mol=minist $\mathrm{y}==" \mathrm{~mol} "$

15 . gen mcom=ministry=="mcom"

16 . gen miti=ministry=="miti"

17 . gen mhw=ministry=="mhw"

18 .

19. gen entry73=ent ryyr==1973

20 . gen e $7172=($ entryyr $>1970$ \& entryyr $<1973)$

21 . gen e7475=(entryyr==1974 | entryyr==1975)

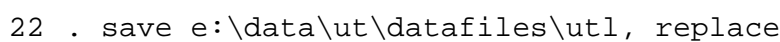

file e:\data\ut\datafiles\utl.dta saved

23.

24 . reg total entry73 e7172 e7475 maff mof mot epa mol mcom miti mhw

\begin{tabular}{r|crc} 
Source & SS & df & MS \\
\hline $\begin{array}{r}\text { Model } \\
\text { Residual }\end{array}$ & $\mathbf{1 7 3 8 . 4 7 2 2 2}$ & $\mathbf{1 1}$ & $\mathbf{1 5 8 . 0 4 2 9 2 9}$ \\
\hline Total & $\mathbf{2 2 4 0 . 4 5 5 5 6}$ & $\mathbf{8 9}$ & $\mathbf{2 5 . 1 7 3 6 5 7 9}$
\end{tabular}

$\begin{array}{crr}\text { Number of obs }= & \mathbf{9 0} \\ \mathrm{F}(11, \quad 78) & & \mathbf{2 4 . 5 6} \\ \text { Prob }>\mathrm{F} & =\mathbf{0 . 0 0 0 0} \\ \text { R-squared } & = & \mathbf{0 . 7 7 5 9} \\ \text { Adj R-squared } & = & \mathbf{0 . 7 4 4 3} \\ \text { Root MSE } & =\mathbf{2 . 5 3 6 9}\end{array}$




\begin{tabular}{|c|c|c|c|c|c|c|}
\hline total & Coef. & Std. Err. & $\mathrm{t}$ & $P>|t|$ & {$[95 \%$ Conf. $]$} & Interval] \\
\hline entry73 & -1.35 & .8969172 & -1.51 & 0.136 & -3.135625 & 435625 \\
\hline e7172 & 1.35 & .6947491 & 1.94 & 0.056 & -.0331391 & 2.733139 \\
\hline e7475 & 1.9 & .6947491 & 2.73 & 0.008 & .5168609 & 3.283139 \\
\hline maff & 1.277778 & 1.035671 & 1.23 & 0.221 & -.7840843 & 3.33964 \\
\hline mof & 9.277778 & 1.035671 & 8.96 & 0.000 & 7.215916 & 11.33964 \\
\hline mot & 2.833333 & 1.035671 & 2.74 & 0.008 & .7714712 & 4.895195 \\
\hline epa & -6.166667 & 1.035671 & -5.95 & 0.000 & -8.228529 & -4.104805 \\
\hline mol & -3.166667 & 1.035671 & -3.06 & 0.003 & -5.228529 & -1.104805 \\
\hline mcom & .6111111 & 1.035671 & 0.59 & 0.557 & -1.450751 & 2.672973 \\
\hline miti & 6.5 & 1.035671 & 6.28 & 0.000 & 4.438138 & 8.561862 \\
\hline mhw & -2.055556 & 1.035671 & -1.98 & 0.051 & -4.117418 & .0063065 \\
\hline _cons & 13.03889 & .6685226 & 19.50 & 0.000 & 11.70796 & 14.36982 \\
\hline
\end{tabular}

25 . reg utlp entry73 e7172 e7475 maff mof mot epa mol mcom miti mhw

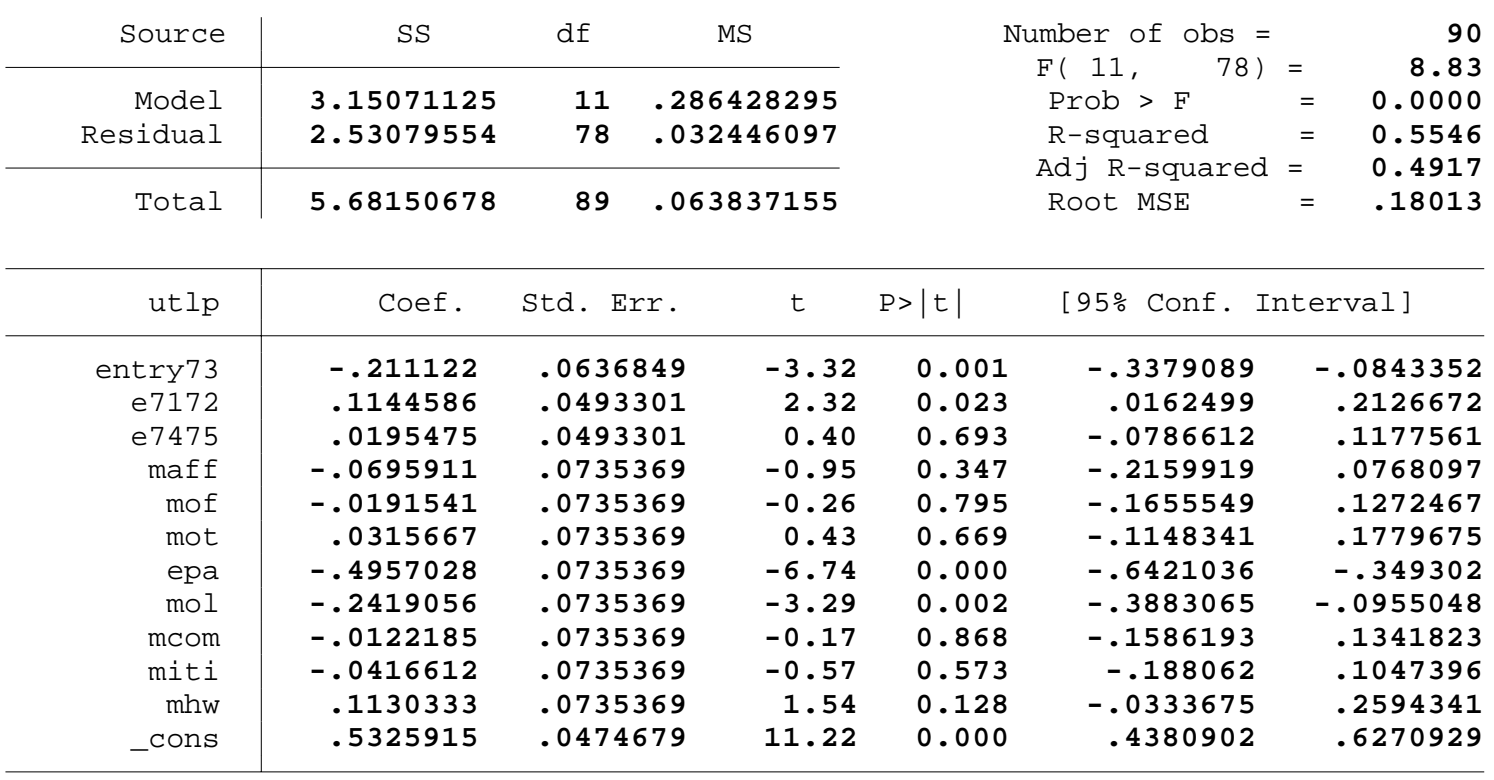

26 .

27 . $\log$ close

log: e: \data\ut\do\utl.smcl

log type: smcl

closed on: 12 May 2004, 16:34:04 